\title{
PENGARUH PIJAT BAYI TERHADAP POLA TIDUR BAYI USIA 0-6 BULAN
}

\author{
Happy Marthalena Simanungkalit ${ }^{1)}$ \\ ${ }^{1}$ Jurusan Kebidanan, Poltekkes Kemenkes Palangka Raya, 73111 \\ e-mail: happy4lena@gmail.com
}

\begin{abstract}
Based on WHO 2012 data included in the journal Pediatrics, there were around 33\% of infants experiencing sleep problems. One of the causes of sleep problems is in fact a parent's mistake in putting the child to sleep. Healthy sleep habits should be implanted from infancy. Objective of this research to determine the effect of massage on the sleep patterns of infants aged 0-6 months. This study used atype study Quasi Experiment with adesign non equilaventwith control group design. The research was conducted from January to March 2018. The population of this study was balyi aged 0-6 months in the work area of Terwan Health Center. The sample is 11 respondents. Data analysis using Chi Square. Based on the results of a statistical test, it was shown that 9 respondents $(81.8 \%)$ had a massage, sleep patterns were not disturbed. Infants who were not massaged were 3 respondents $(27.3 \%)$, sleep patterns were not disturbed. Chi square statistic test shows the value of $\mathrm{P}-$ Value $0.032(\mathrm{P}-\mathrm{Value}<\alpha$ 0.05) which means there are significant differences.
\end{abstract}

Keywords: massaage, sleep patterns.

\begin{abstract}
Abstrak
Berdasarkan data WHO tahun 2012 yang dicantumkan dalam jurnal Pediatrics, tercatat sekitar $33 \%$ bayi mengalami masalah tidur. Salah satu penyebab masalah tidur nyatanya merupakan kesalahan orang tua dalam menidurkan anak. Kebiasaan tidur yang sehat seharusnya ditanamkan sejak bayi.Tujuan penelitian intuk mengetahui pengaruh pijat terhadap pola tidur bayi usia 0-6 bulan. Penelitian ini menggunakan jenis penelitian Quasi Eksperimen dengan rancangan non equilavent with control group design. Penelitian ini dilaksanakan pada bulan Januari sampai Maret 2018. Populasi penelitian ini adalah balyi usia 0-6 bulan di wilayah kerja Puskesmas Terwan. Sampel dengan jumlah 11 responden. Analisis data menggunakan $C h i$ Square. Berdasarkan hasil penelitian uji statistik menunjukkan sebesar 9 responden $(81,8 \%)$ bayi yang dilakukan pijat, pola tidur tidak terganggu. Bayi yang tidak dipijat sebanyak 3 responden (27,3\%), pola tidur tidak terganggu. Uji statistik chi square menunjukkan nilai $P$-Value $0,032(P$-Value $<\alpha 0,05)$ yang bearti terdapat perbedaan yang signifikan.
\end{abstract}

Kata Kunci : pijat bayi, pola tidur

\section{PENDAHULUAN}

Perkembangan pada bayi merupakan suatu proses yang hakiki, unik, dinamik, dan berkesinambungan. Faktor yang mempengaruhi perkembangan bayi ada dua, yaitu factor genetic dan lingkungan. Faktor genetik merupakan faktor bawaan yang diturunkan melalui instruksi genetik yang terkandung di dalam sel telur yang telah dibuahi dan faktor lingkungan yang merupakan faktor di sekeliling bayi yang menentukan tercapai atau tidaknya potensi genetik. Banyak faktor yang menghambat perkembangan tersebut sehingga bayi tidak dapat mencapai potensi genetik yang seharusnya, diantaranya adalah pemberian nutrisi dan 
stimulasi (massage bayi) (Sulung dan Gayatri, 2015).

Berdasarkan data WHO (2012) yang dicantumkan dalam jurnal Pediatrics, tercatat sekitar $33 \%$ bayi mengalami masalah tidur. Sementara para peneliti Cincinnati Children's Hospital Medical Center menyatakan masalah tidur pada bayi tidak selalu hilang saat mereka dewasa. Salah satu penyebab masalah tidur nyatanya merupakan kesalahan orang tua dalam menidurkan anak. Kebiasaan tidur yang sehat seharusnya ditanamkan sejak bayi.

Di Indonesia cukup banyak bayi yang mengalami masalah tidur, yaitu sekitar $44,2 \%$ bayi mengalami gangguan tidur seperti sering terbangun di malam hari. Namun lebih dari $72 \%$ orang tua menganggap gangguan tidur pada bayi bukan suatu masalah atau hanya masalah kecil, hal tersebut diungkapkan oleh sebuah penelitian pada tahun 2014-2015 yang dilaksanakan di lima kota besar di Indonesia (Jakarta, Bandung, Medan, Palembang dan Batam). Menurut hasil penelitian Sekartini tahun 2014, yang dilakukan di 5 kota yaitu Jakarta, Bandung, Medan, Palembang dan Batam dengan jumlah responden 385 orang, diperoleh data $51,3 \%$ bayi mengalami gangguan tidur, $42 \%$ jam tidur malamnya kurang dari 9 jam, terbangun malam hari lebih dari tiga kali dan lama terbangun pada malam hari lebih dari satu jam. (Rini Sekartini, 2010).

Berdasarkan uraian di atas maka rumusan masalah dalam penelitian ini adalah apakah ada pengaruh pijat bayi terhadap pola tidur bayi usia 0-6 bulan di Puskesmas Terawan.

Tunjuan dari penelitian ini adalah untuk mengetahui pengaruh pijat bayi terhadap pola tidur bayi usia 0-6 bulan di Puskesmas Terawan.

\section{METODE PENELITIAN}

Dalam penelitian ini penulis menggunakan metode penelitian Quasi Eksperimen. Desain yang digunakan dalam penelitian ini adalah non equivalent with control group desain. Dengan demikian hasil perlakuan dapat diketahui lebih akurat, karena dapat membandingkan dengan keadaan sebelum diberi perlakuan. (Sastroasmoro, 2014).

Populasi dalam penelitian ini adalah bayi usia $0-6$ bulan di Wilayah Kerja Puskesmas Terawan Tahun 2019. Pengambilan sampel ini dilakukan dengan tehnik Purposive Sampling. 
HASIL DAN PEMBAHASAN

\section{Hasil Penelitian}

1. Analisis Univariat

Tabel 1. Distribusi Frekuensi Pola Tidur Bayi pada Kelompok Intervensi

\begin{tabular}{ccc}
\hline PolaTidur & $\mathrm{n}$ & $\%$ \\
\hline Tergangu & 2 & $18,2 \%$ \\
Tidak & 9 & $81,8 \%$ \\
terganggu & & \\
\hline Total & 28 & $100 \%$ \\
\hline
\end{tabular}

Berdasarkan Tabel 1, distribusi frekuensi pijat bayi terhadap pola tidur bayi usia 3-6 bulan di Puskesmas Terawan pada kelompok intervesi, yaitu pola tidur bayi tertinggi pola tidur bayi terganggu sebesar 2 responden $(18,2 \%)$ dan pola tidur yang terendah pola tidur bayi tidak terganggu sebesar 9 responden $(81,8 \%)$.

Tabel 2. Distribusi Frekuensi Pola Tidur Bayi pada Kelompok Kontrol

\begin{tabular}{ccc}
\hline PolaTidur & $\mathrm{n}$ & $\%$ \\
\hline Tergangu & 8 & $72,7 \%$ \\
Tidak & 3 & $27,3 \%$ \\
terganggu & & \\
\hline Total & 11 & $100 \%$
\end{tabular}

Berdasarkan Tabel 2, distribusi frekuensi pijat bayi terhadap pola tidur bayi usia 3-6 bulan di Puskesmas Terawan pada kelompok kontrol, yaitu pola tidur bayi tertinggi pola tidur bayi tidak terganggu sebesar 3 responden $(27,3 \%)$ dan pola tidur yang terendah pola tidur bayi terganggu sebesar 8 responden $(72,7 \%)$.

2. Aanalisis Bivariat

Hasil analisis Uji Chi Square penelitian tentang pengaruh pijat bayi terhadap pola tidur bayi usia 0 - 6 bulan di puskesmas terawan tahun 2019 sebagai berikut:

Tabel 3. Analisis Pengaruh Pijat Bayi terhadap Pola Tidur

\begin{tabular}{cccccc}
\hline Pijat & \multicolumn{4}{c}{ PolaTidur } & \multirow{2}{P}{} \\
\cline { 2 - 5 } & $\begin{array}{c}\text { Tidak } \\
\text { terganggu }\end{array}$ & $\%$ & Terganggu & $\%$ & value \\
\hline Pijat & 9 & 81,8 & 2 & 18,2 & \\
Tidak & 3 & 27,3 & 8 & 72,7 & 0,032 \\
Pijat & & & & & \\
\hline
\end{tabular}

Tabel 4.3 Hasil analisis menunjukkan sebesar 9 responden $(81,8 \%)$ bayi yang dilakukan pijat, pola tidur tidak terganggu. Bayi yang tidak dipijat sebanyak 3 responden $(27,3 \%)$, pola tidur tidak terganggu. Uji statistik chi square menunjukkan nilai $P$-Value 0,032 (P-Value $<\alpha$ 0,05) sehingga dapat disimpulkan terdapat hubungan signifikan antara pijat dengan pola tidur bayi atau dapat dikatakan ada pengaruh pijat terhadap pola tidur bayi.

\section{Pembahasan}

Dari hasil penelitian tentang pengaruh pijat bayi terhadap pola tidur bayi usia $0-6$ bulan di Puskesmas 
Terawan tahun 2019, dari 11 responden yang dilakukan pijat ada 9 responden $(81,8 \%)$ pola tidur tidak terganggu dan ada 2 responden $(18,2 \%)$ pola tidur terganggu. Sedangkan dari 11 responden yang tidak dilakukan pijat ada 3 responden $(27,3 \%)$ pola tidur tidak terganggu dan ada 8 responden $(72,7 \%)$ pola tidur terganggu.

1. Pola Tidur Bayi Kelompok Intervensi

Distribusi frekuensi pijat bayi terhadap pola tidur bayi usia 3-6 bulan di Puskesmas Terawan pada kelompok intervesi, yaitu pola tidur bayi tertinggi pola tidur bayi terganggu sebesar 9 responden $(81,8 \%)$ dan pola tidur yang terendah pola tidur bayi tidak terganggu sebesar 2 responden $(18,2 \%)$. Berdasarkan penelitian tersebut diketahui bahwa pola tidur yang tertinggi yaitu pola tidur bayi terganggu.

Salah satu cara mengatasi gangguan tidur yaitu dengan dipijat, karena bayi yang dipijat tidurnya akan lebih lelap (Roesli, 2013).

2. Pola Tidur Bayi Pada Kelompok Kontrol

Distribusi frekuensi Pijat bayi terhadap pola tidur bayi usia 3-6 bulan di Puskesmas Terawan pada kelompok kontrol, yaitu pola tidur bayi tertinggi pola tidur bayi tidak terganggu sebesar 8 responden $(72,7 \%)$ dan pola tidur yang terendah pola tidur bayi terganggu sebesar 3 responden $(27,3 \%)$.

Pijat bayi tampaknya dapat menjadi solusi praktis untuk menyelesaikan masalah gangguan tidur. Umumnya, bayi yang dipijat akan tertidur lebih lelap, sedangkan pada waktu bangun konsentrasinya akan penuh (Roesli, 2013).

3. Pengaruh Pijat Bayi terhadap Pola Tidur Bayi usia $0-6$ bulan

Uji statistik chi square menunjukkan nilai $P$-Value 0,032 ( $P$ Value $<\quad \alpha 0,05)$ sehingga dapat disimpulkan terdapat hubungan signifikan antara pijat dengan pola tidur bayi atau dapat dikatakan ada pengaruh pijat terhadap pola tidur bayi.

Penelitian ini sejalan dengan penelitian yang pernah dilakukan oleh Devi Indah Nurmalasari, 2016, Pengaruh Pijat Bayi dengan Kualitas Tidur Bayi usia 3-6 bulan di Desa Bandung Kecamatan Diwek Kabupaten Jombang. Hasil statistik menunjukkan bahwa pijat Bayi 
memiliki pengaruh dengan kualitas tidur bayi dengan nilai $P$-Value $=$ 0,002 dimananilai $P$-Value $<\alpha 0,05$.

Peningkatan kualitas tidur pada bayi yang diberi pemijatan tersebut disebabkan oleh adanya peningkatan kadar sekresi serotonin yang dihasilkan pada saat menjadi tenang, nyaman dan mengurangi frekuensi menangis (Roesli, 2013).

Rasa nyaman pada bayi setelah dipijat itu seperti apa yang dijelaskan dalam konsep Teori Kenyamanan (Theory of Comfort Katherine Kolcaba) yang menjelakan teori kenyamanan adalah kebutuhan kenyamanan, intervensi kenyamanan, intervening variables, peningkatan, kenyamanan health seeking behaviour (HSBS) dan Integritas Institusional.. Pijat termasuk dalam intervensi kenyamanan (Comfort Measure) yaitu intervensi yang sengaja dirancang untuk meningkatkan kenyamanan klien atau keluarga (Kolcaba 2003 dalam Herlina 2012).

\section{SIMPULAN}

1. Didapatkan gambaran pola tidur bayi usia 0-6 bulan yang di pijat di
Puskesmas Terawan pada kelompok intervesi adalah tidak terganggu, sebelum $0 \%$ dan sesudahnya $81,8 \%$.

2. Didapatkan gambaran pola tidur bayi usia 0-6 bulan kelompok kontrol di Puskesmas Terawan pada kelompok intervesi adalah pretest $100 \%$ dan postest $72,7 \%$.

3. Hasil analisis dari uji statistik chi square menunjukkan nilai $P$-Value 0,032 (P-Value $<\alpha 0,05)$ yang berarti terdapat perbedaan yang signifikan antara pijat dengan pola tidur bayi. Dapat disimpulkan bahwa ada pengaruh pijat bayi terhadap pola tidur bayi usia $0-6$ bulan di Puskesmas Terawan tahun 2019.

\section{DAFTAR PUSTAKA}

Sulung, N. dan Gayatri, A. 2015. Efektivitas Massage Baby Terhadap Peningkatan Berat Badan Bayi Usia 3-4 Bulan Di BPS BUNDA Kecamatan Mandiangin Koto Selayan Bukittinggi Tahun 2014. Menara Ilmu. Volume 9. Nomor 57.

Sekartini, Rini. 2010. Pentingnya Pola Tidur Berkualitas Untuk Bayi. http://www.

mentorhealthcare.com/news.php?n ID $=92 \&$ action+detail. Diakses 
Mahakam Midwifery Journal, Vol 3, No. 1, November 2019 : 18-23

tanggal 14 Nopember 2018

Sastroasmoro, S. Sofyan I. Dasar-Dasar

Metodologi Penelitian Klinis Edisi

ke-5, Jakarta :CV. Sagung Seto. 2014.p:130-7, 352-17

Roesli, U. 2013. Pedoman Pijat Bayi
Prematur \& Bayi Usia 0-3 bulan.

Jakarta : Trubus Agriwidya

Herlina Widyaningrum. (2012). Pijat refleksi dan 6 terapi alternative lainnya.Yogyakarta:

Medpress,2012 